\title{
Aspek hukum pidana cyberbullying di media sosial
}

\section{Hatarto Pakpahan}

Hatarto Pakpahan; Fakultas Hukum Universitas Merdeka Malang; Jl. Terusan Raya Dieng Nomor 6264; Malang; 65146; Jawa Timur; Indonesia.

\begin{tabular}{l} 
A R T I C L E I N F O \\
\hline Article history: \\
Received 2020-09-02 \\
Received in revised form \\
2020-11-02 \\
Accepted 2020-12-01
\end{tabular}

Kata kunci:

Bully; Cyberbullying; Media Sosial.

Keywords:

Bully; Cyberbullying; Social Media.

DOI: https://doi.org/10.26905/

idjch. v11i3. 5718.

How to cite item:

Pakpahan, H. (2020). Aspek

hukum pidana cyberbullying di

media sosial. Jurnal Cakrawala

Hukum, 11(3). 250-258.

doi:10.26905/idjch.v11i3.5718.

\begin{abstract}
Abstrak
Perkembangan teknologi informasi saat ini memicu pada penggunaan media sosial yang semakin gencar. Namun penggunaan media sosial tersebut tentu menimbulkan sisi positif maupun negatif. Penggunaan sosial media dalam hal yang posditif akan sangat membantu pengguna untuk mempermudah aktifitas pekerjaan maupun dalam hal memperoleh informasi atau data yang diinginkan. Namun Penyalahgunaan media sosial yang menimbulkan kerugian bagi orang lain seperti tindakan "Bully" yang menimbulkan dampak kerugian akibat tindakan tersebut kepada orang lain merupakan bentuk tindak pidana cyber bullying. Metode yang digunakan dalam tulisan ini adalah penelitian hukum normatif deskriptif. Dalam tulisan terkait menyajikan gambaran terkait aspek hukum pidana cyber bullying dan juga korelasi cyber bullying dengan media sosial. Tindakan "Bully" yang dilakukan tersebut secara konvensional dan menyerang nama baik atau kehormatan orang lain termasuk yang dikemukakan dimuka umum maka perbuatan tersebut bisa diancam pidana dengan ketentuan KUHP. Tindakan "Bully" yang dilakukan di dunia maya dengan menggunakan jaringan internet (online) yang bermuatan melanggar kesusilaan, penghinaan, pemerasan atau pengancaman dan juga "Bully" dalam bentuk informasi elektronik dimedia sosial yang berisi ancaman kekerasan atau dalam bentuk menakut nakuti secara pribadi diancam pasal 29 jo Pasal 45B UU RI No. 19 Tahun 2016 perubahan dari UU RI No. 11 Tahun 2008 tentang ITE.
\end{abstract}

Abstract
The current development of information technology has led to the increasingly
intense use of social media. However, the use of social media certainly raises both
positive and negative sides. The use of social media in positive terms will greatly
help users to facilitate work activities and in terms of obtaining the desired informa-
tion or data. However, misuse of social media that causes harm to others, such as the
act of "Bully" which causes the impact of the loss as a result of this action to others
is a form of cyber bullying. The method used in this paper is descriptive normative

Corresponding Author:

* Hatarto Pakpahan.

E-mail address: hatarto.pakpahan@unmer.ac.id 


\section{Aspek hukum pidana cyberbullying di media sosial}

Hatarto Pakpahan

legal research. In a related article, it presents an overview regarding the legal aspects of cyber bullying and also the correlation between cyber bullying and social media. Such acts of "bullying" conventionally and attacking the good name or honor of others, including those expressed in public, can be punishable by the provisions of the Criminal Code. The act of "Bully" which is carried out in cyberspace by using the internet network (online) is charged with violating decency, insults, extortion or threats and also "Bully" in the form of electronic information on social media that contains threats of violence or in the form of personal frightening are threatened by article 29 in conjunction with Article 45B of Law of the Republic of Indonesia No. 19 of 2016 amendments to the Law of the Republic of Indonesia No. 11 of 2008 concerning ITE.

\section{Pendahuluan}

Tindakan menyampaikan pendapat dimuka umum adalah bagian dari hak setiap warga Negara untuk mengemukakan pendapat secara bebas dan bertanggung jawab namun tentu harus sesuai dengan peraturan perundang undangan yang berlaku. Sehingga dapat dimaknai secara jelas bahwa penggunaan hak kebebasan berpendapat juga dituntut adanya kemampuan pertanggung jawaban dan tidak hanya dilakukan semaunya, seperti penyampaian di muka umum yang berakibat penghinaan, pelecehan, fitnah bahkan Intimidasi. Dalam bahasa yang lebih sederhana kebebasan berpendapat termasuk mengutarakan pendapat dimedia sosial yang mengganggu atau merugikan hak orang lain akan dimintai pertanggungjawabannya secara hukum.

Istilah telematika berasal dari bahasa Perancis yang merupakan asal kata telematique yang menggabarkan berpadunya sistem jaringan komunikasi dan teknologi informasi (Makarim, 2004). Seiring dengan kebutuhan masyarakat di bidang Teknologi dan Informasi, Arus globalisasi di masa kini semakin hari semakin berkembang dan meningkat sangat cepat. Terutama dibidang teknologi dan Informasi, begitu banyak dampak yang dapat dirasakan oleh manusia diseluruh dunia. Penemuan teknologi yang semakin canggih setiap harinya tentu tentu membawa dampak yang positif bagi manusia dikarenakan dapat mempermudah dalam melakukan pekerjaan

Lalu dalam hal perkembangan dunia dalam teknologi komunikasi, di era globalisasi syarat akan penggunaan media elektronik, dimana media yang menggunakan jaringan tersebut menyediakan berbagai macam kemudahan untuk dapat menjangkau berbagai informasi di seluruh dunia hanya dengan menggunakan jaringan internet segala informasi dapat terjangkau dengan sangat mudahnya. Media sosial yang kini muncul dikalangan masyarakat banyak dijadikan sarana utama untuk memperoleh informasi penting, contoh beberapa media sosial yang banyak di pergunakan remaja bahkan orang dewasa seperti WhatsApp, facebook, instagram, twitter, Path, dll.. Meskipun begitu berkembangnya teknologi saat ini memiliki kandungan yang positif dan bahkan negatif.

Ada beberapa dampak positif dan dampak negatif akibat dengan penggunaan kecanggihan teknologi dalam hal penggunaan sosial media. Dampak positif nya yakni, kemudahan dalam mengakses berbagai informasi dengan menggunakan jaringan internet, kemudahan dalam berkomunikasi jarak jauh, kemudahan dalam sarana transportasi, diciptakannya mesin canggih, kemudahan dalam transaksi jual beli. Kemudan dampak negatif yang ditimbulkan nya yakni, maraknya kejahatan didunia maya (cybercrime), tergesernya tenaga 


\section{Jurnal Cakrawala Hukum, Volume 11 No. 3 Desember 2020}

ISSN PRINT 2356-4962 ISSN ONLINE 2598-6538

manusia, munculnya individualisme, masuknya budaya buruk dari negara lain dan ketergantungan terhadap teknologi (Bustomy, 2017).

Penggunaan teknologi internet ini merupakan fenomena yang sangat luar biasa (Danrinvanto, 2010). Betapa tidak bahwa konsumsi internet masyaraat indonesiaa bahkan dunia terlebih ditengah pandemi covid-19 saat ini meningkat dengan sangat pesat, karena dengan tehnologi internet maka aktifitas kita bisa melampaui banyak hal (tanpa batas), menghilangkan sekat dan bahkan jarak dan juga penggunaan jaringan internet dengan banyaknya kemudahan tersebut tentunya dengan biaya yang murah. Wajar jika peradapan dan kehidupan sosial masyarakat saat ini berkembang begitu cepat. Namun disisi lain jika salah dalam penggunaan atau penggunaan internet untuk suatu kejahatan maka hal itu menjadi sarana efektif perbuatan melawan hukum (Ramli, 2004).

Perkembangan penggunaan jaringan Teknologi dan Informasi di Indonesia mengalami peningkatan yang siknifikan, maraknya kejahatan yang terjadi di dunia maya sendiri menunjukkan bahwa kemajuan Teknologi dan Informasi di Indonesia sendiri hanya diterima secara mentahmentah oleh masyarakat, banyak yang menyalahgunakan Teknologi dan Informasi seperti hal nya di sosial media. Penyalahgunaan yang kurang bijak bagi para pengguna sosial media dan kurang nya pengetahuan sehingga menimbulkan sebuah kejahatan di dunia maya. Contoh nya seperti cyberbullying yang belakangan ini sedang marak terjadi seperti halnya negara di Indonesia saat ini.

Cyberbullying atau yang kita kenal dengan istilah perundungan di dunia maya dengan menggunakan jaringan internet. Dalam bahasa indonesia "bully" memiiki padanan pengertian dengan "Penindasan /perisakan/perundungan". Cyberbullying adalah suatu tindakan dengan tujuan supaya target kesulitan membela diri yang dilakukan orang atau kelompok orang dengan cara atau perlakuan kasar dengan bantuan jaringan internet dimana tindakan tersebut dilakukan terus menerus dan berulang ulang (Marpuajihan, 2014).

Kemudian dengan berdasarkan pada riset KEMKOMINFO dengan UNICEF (2014) telah menyatakan sebagian besar remaja di Indonesia telah menjadi korban cyberbullying pada tahun 2011 hingga 2013. Lebih lanjut dikemukakan bahwa "Sembilan dari sepuluh siswa atau 89 persen responden berkomunikasi secara online dengan teman teman 56 persen beromunikasi online dengan keluarga 25 persen berkomunikasi online dengan guru, sebanyak 13 persen responden mengaku menjadi korban cyberbullying melalui jaringan internet dengan bentuk hinaan dan ancaman dengan sampel penelitian 400 anak dan remaja di rentang usia 10 hingga 19 tahun (Machsun, 2016)".

Tindak pidana perundungan yang begitu banyak yang kini terjadi di karenakan perkembangan teknologi yang semakin pesat saat ini dan marak terjadi di berbabagi Negara yaitu tindak pidana cybercrime (cybercspace / cybervirtual). Cyberbullying dikategorikan sebagai bullying secara verbal, (perundungan yang dilakukan di dunia maya), yang dimana tindakan tersebut dilakukan untuk mengejek, mengolok, menghina, mencela, bahkan mengancam korban atau pengguna media sosial yang lain. Adapun jenis jenis cyberbullying yaitu: flamingharassment (gangguan), impersonation (peniruan), denigration (pencemaran nama baik), outing trickey (tipu daya), exclusion (pengeluaran), cyberstalking (Willard, 2014).

Dengan adanya tindakan cyberbullying tersebut yang dilakukan pelaku terhadap korban menjadi ketakutan tersendiri yang di rasakan oleh korban. Sehingga hal tersebut menimbulkan dampak negatif terhadap psikologi koban, seperti hal nya, rasa tidak percaya diri, ketakutan, tekanan mental dan bahkan bisa jadi membuat korban melakukan tindakan bunuh diri sebagai dampak kekerasan non verbal yang dialaminya. Minimnya kasus cyberbullying yang terungkap di Indonesia bukan berarti kasus tersebut jarang terjadi, namun 
bisa dipahami mayoritas pengguna sosial media atau jaringan internet saat ini banyakan dari kalangan anak muda yang minim pengetahuan dan pemahaman terkait dengan cyberbullying.

Sehingga banyak pengguna sosial media yang tidak menyadari kalau dirinya sudah menjadi korban dan tidak melakukan laporan polisi karena tidak mengerti dan tidak mengetahui peraturan cyberbullying dan peraturan lainnya terkait dengan undang undang Informasi dan Transaksi Elektronik (ITE). Oleh sebab itu dalam tulisan ini akan mencoba menjelaskan gambaran umum cyberbullying dan juga aspek hukum pidana cyberbullying dimedia sosial.

\section{Metode}

Jenis peneltian hukum yang digunakan dalam penulisan adalah jenis penelitian yuridis normatif, adapun penelitian ini mengkaji dan meneliti peraturan perundang-undangan yang tersedia yang terkait dengan permasalahan terkait dan juga berbagai buku literatur terkait. Lebih lanjut peneliti akan mencoba mengkaji / mendiskripsikan norma pasal-pasal terkait dari peraturan peraturan terkait sekaligus mengemukakan berbagai permasalahan berkaitan norma pasal berkaitan dengan fenomena terkait terlebih dalam UU RI No. 19 Tahun 2016, KUHP dan UU undangundang terkait lainnya.

\section{Pembahasan}

\subsection{Cyberbullying di media sosial}

Semakin meningkatnya penggunaan tehnologi informasi dalam melakukan interaksi sosial dengan menggunakan media sosial juga berimbas pada timbulnya pihak-pihak yang tidak bertanggung jawab yang memiliki motivasi untuk menggunakan sarana media sosia dalam melancarkan niat kejahatannya. Kejahatan yang dimaksudkan dalam pembahasan ini adalah cyberbullying.
Tindakan "bully" pada dasarnya kejahatan yang terjadi dikalangan anak-anak yang umumnya dilakukan secara konvensional antar individu atau antar kelompok bermain kepada orang tertentu. Seiring berjalannya waktu dan perkembangan tehnologi informasi saat ini masyarakat juga telah melakukan kegiatan sosialnya di media sosial termasuk tindakan membully atau perundungan di sosial media dengan cakupan dan wilayah yang jauh lebih luas.

Bully dalam kehidupan sehari hari dalam bahasa indonesia kita kenal juga dengan istilah: Penindasan, perundungan atau perisakan (ada yang dilakukan secara konvensional dan ada yang dilakukan dengan menggunakan tehnologi internet). Lebih lanjut Sameer Hinduja dan Justin W. Patchin menjelaskan bahwa cyberbullying adalah tindakan yang dilakukan secara sadar untuk merugikan atau menyakiti orang lain melalui penggunaan komputer (jejaring sosial dunia maya), telepon seluler dan peralatan elektronik lainnya.

Dalam bahasa yang lebih sederhana cyberbullying dapat kita maknai dengan serangkaian tindakan yang menggunakan jaringan internet / tehnologi informasi yang dalam hal ini tindakan tersebut adalah dalam bentuk kekerasan atau penindasan dari orang atau sekelompok orang (anak atau remaja) yang lebih berkuasa atau lebih kuat dengan tujuan untuk mempermalukan, membuat marah, menakuti bahkan menyakiti orang lain yang menjadi sasarannya serta tindakan tersebut dilakukan secara berulang ulang.

Jika dilihat dari berbagai literatur Bentuk tindakan bullying bisa jadi dalam bentuk kekerasan Fisik seperti tindakan menendang, memukul, merampas, merusak, memaksa, melakukan pemerasan dan tindakan kekerasan lainnya. Tindakan dalam bentuk Verbal menertawakan, mengejek, memberika cap atau sebutan negatif, mengancam, menyebarkan berita bohong, menggoda, memberikan komentar di fitur komentar media sosial atau membuat postingan yang menyakitkaan atau 


\section{Jurnal Cakrawala Hukum, Volume 11 No. 3 Desember 2020}

ISSN PRINT 2356-4962 ISSN ONLINE 2598-6538

memalukan, pelecehan sexual, intimidasi, dan berbagai tindakan lainnya. Sedangkan tindakan dalam bentuk relasional seperti mengucilkan teman, tidak membolehkan teman ikut bermain, tidak mengajar teman belajar bersama, mengucilkan teman dari grup sosial media, dll.

Sedangkan dampak negatif sebagai akibat dari Cyberbullying adalah sangat beragam seperti dampak mental (merasa malu, takut, kesal, bodoh, bahkan marah, trauma), dampak Secara Emosional (merasa malu, hilang percaya diri, lesu / tidak bersemangat) dan juga dampak Secara Fisik lelah, kesakitan, bahkan bisa jadi membahayakan nyawa.

Hinduja dan Patchin menjelaskan tiga karakteristik Cyberbullying yaitu: a). Disengaja, Perilaku yang disengaja dan sudah memiliki tujuan tertentu. Kejadian ini dapat terjadi kapan saja selama terkoneksi dengan internet. Cyberbullies dalam melakukan cyberbullying telah menetapkan target yang akan disakiti. Seperti halnya, para pelaku sudah tau akun korban yang akan disakiti,karena pelaku memiliki bentuk fisik yang buruk dan memungkinkan pelaku untuk melakukan intimidasi terhadap korban; b). Harm (membahayakan), Bahaya yang ditimbulkan cyberbullying dapat terus menerus diselesaikan korbannya karena apa yang dilakukan cyberbulies dapat distribusikan melalui internet dalam hitungan detik keseluruh dunia. Contoh tindakan yang membahayakan nya adalah dengan melakukan pengancaman yang dilakukan pelaku terhadap korban; c). Diulang (berulangulang), Perilaku agresiter harus dilakukan berulang kali, sehingga membuat korban terus menerus khawatir tentang apa yang dilakukan oleh cyberbullies selanjutnya. Contohnya adalah, pelaku dapat mengakses akun korban sehingga dapat dilakukan secara berulang, sehingga korban merasa tidak berdaya untuk membela diri.

Berdasarkan Jurnal Jafray penjelasan mengenai Motif Cyberbullying adalah jika dalam bullying conventional pelaku melakukan bullying karena: "kurangnya perhatian, kecenderungan permusuhan, korban kekerasan merupakan motif yang mendasari tindakan cyberbullying", yakni (Jaffray, 2016): a). Dendam “The Vengeful Angel", Dalam iklim penuh konflik budaya ini terdapat banyak kelompok sosial yang tidak bisa didamaikan dan dirukunkan dan selalu saja terlibat dalam ketegangan, persaingan dan benturan sosial diwarnai rasa benci dan dendam kesumat; b). Pelaku yang termotivasi (Motivated Offender), Motivasi pelaku melakukan kejahatan internet sangatlah banyak antara lain pembajakan, balas dendam, pencurian atau sekedar iseng; c). Keinginan untuk dihormati, Pelaku menggunakan kewenangan untuk memperlihatkan bahwa pelaku cukup kuat dalam membuat dan mengontrol orang lain dengan rasa takut; d). Mens Girl, Ini terjadi ketika cyberbully bosan dan mencari hiburan. Pelaku ini yang paling matang dari semua jenis cyberbullying. biasanya dalam Mens Girl situasi intimidasi cyberbullies adalah perempuan. Yang paling sering pelaku lakukan adalah mengintimidasi para gadis atau anak laki-laki.

Berdasarkan uraian tersebut dapat kita pahami mengenai sebab-sebab pelaku kejahatan cyberbullying melakukan kejahatan dan menggunakan sosial media, dan alat elektronik dalam melakukan kejahatan dapat dipahami bahwa dengan menggunakan sosial media identitas yang dimiliki oleh pelaku kejahatan dapat disamarkan dengan mengggunakan akun-akun palsu dengan identitas palsu, kemudian menggunakan jejaring internet tanpa batas dan dapat di jangkau dimana pun dengan biaya yang relatif murah. Lain dari pada itu, fitur keamanaan terhadap pengguna media sosial yang sangatlah lemah sehingga para pelaku dapat dengan mudah berkomunkasi kepada para pengguna yang lainnya, lalu kurang nya kesadaran masyarakat terhadap dampak dari kejahatan yang ditimbulkan di sosial media bagi para korban. Sehingga para pelaku masih merasa aman saat melakukan kejahatannya. 


\subsection{Aspek pidana cyberbullying}

Praktek kejahatan Cyberbullying saat ini begitu marak terjadi, bahkan seringkali perbuatan bullying menjadi viral di media sosial bahkan pemberitaan media televisi sebagaimana yang sudah kita saksikan selama ini, akan tetapi dari sekian yang viral tersebut sangat jarang kita bisa mengikuti perkembangan penanganan kasus hingga diputus oleh hakim di pengadilan. Sehingga jika hanya sebatas viral dalam perbuatan bullying- nya saja maka tentu hal tersebut menjadi potensi menambah penderitaan / kerugian kepada sikorban, akan tetapi ada juga kasus bullying yang menjadi viral yang pada akhirnya menjadi sumber rejeki bagi sikorban karena bantuan atas keprihatinan masyarakat luas bahkan menjadi bintang tamu dan dibayar diberbagai stasiun televisi.

Baru baru ini kasus bullying yang sempat viral yaitu seorang anak yang yang keterbelakangan mental diolok olok temannya bahkan beberapa kali melakukan tindakan kekerasan, setelah viralnya video tersebut akhirnya banyak netizen yang bersimpati kepada anak korban tersebut yaitu dengan cara membelikan sepeda untuk digunakan akomodasi sekolah, pemberian uang biaya hidup, bantuan beasiswa sekolah dan berbagai bantuan lainnya. Kasus yang demikian merupakan kasus anak korban bullying yang kebetulan sedang beruntung, sedangkan kasus Cyberbullying yang lain yang belum terungkap dan yang tidak beruntung masih jauh lebih banyak.

Terminologi Cybercrime secara umum digunakan untuk menggambarkan suatu kejahatan yang dilakukan degan menggunakan alat bantu / perantara berupa suatu tehnologi seperti komputer atau dengan jaringan internet. Namun terminologi diberbagai negara berbeda-beda sesuai dengan tujuan dan luas lingkup pengaturannya (Suseno, 2012).

Cyberbulying is the use of technology to intimidate, victimize, or bully anindividual or group, cyberbullying adalah pengunaan teknologi untuk mengintimidasi, menjadikan korban, mengganggu individu atau sekelompok orang. Cyberbullying individu atau kelompok dengan sengaja menggunakan informasi dan komunikasi yang melibatkan teknologi elektronik untuk menfasilitasi pelecehan dengan sengaja dan berulang atau ancaman terhadap individu atau kelompok lain dengan mengirim atau posting teks kejam/ atau menggunakan sarana teknologi (Mason, 2012).

Cyberbullying telah menjadi sebuah fenomen negatif sejak berkembangnya teknologi dan informasi dalam bidang internet, kemudian dalam dunia remaja/ anak-anak fenomena ini haruslah dapat ditanggulangi untuk mencegah terjadinya budaya bullying yang dilakukan melalui media sosial. Selain itu juga cyberbullying juga tampaknya akan menjadi sangat berbahaya bagi kalangan anak anak dan remaja melebihi bentuk dan dampak bullying yang ada disekolah.

Jika melihat ketentuan hukum positif sesungguhnya sudah ada ketentuan hukum yang mengatur terkait perundungan didunia maya, seperti pasal 27 ayat (3) Undang-undang Nomor 19 Tahun 2016 perubahan atas UU No. 11 Tahun 2008 tentang Informasi dan Transasksi Elektronik (UU RI No. 19 Tahun 2016 perubahan dari UU RI No. 11 Tahun 2008 tentang ITE) menyatakan bahwa "setiap orang dengan sengaja dan tanpa hak mendistribusikan dan/atau mentranmisikan dan/atau membuat dapat diaksesnya informasi elektronik dan/atau pencemaran nama baik." Kemudian pasal 27 ayat (4) dinyatakan bahwa "setiap orang dengan sengaja dan tanpa hak mendistribusikan dan/atau mentranmisikan dan/atau membuat dapat diaksesnya Informasi Elektronik dan/atau Dokumen Elektronik yang memiliki muatan pemerasan dan/atau pengancaman."

Memperhatikan ketentuan pasal tersebut adapun tindakan bullying yang dilarang adalah perbuatan yang berkaitan dengan pencemaran nama baik dan juga suatu perbuatan yang memuat pemerasan dan pengancaman yang dilakukan didunia maya termasuk dalam aktifitas media sosial. Sepin- 


\section{Jurnal Cakrawala Hukum, Volume 11 No. 3 Desember 2020}

ISSN PRINT 2356-4962 ISSN ONLINE 2598-6538

tas jika memperhatikan ketentuan tersebut sesungguhnya tidak diuraikan dengan unsur yang lebih jelas, seperti hal nya hanya terdapat unsur penghinaan, pencemaran nama baik, dan pengancaman dan pemerasan dalam KUHP. Oleh sebab itu makna pencemaran nama baik mengacu pada ketentuan umum dalam peraturan perundang undangan sekalipun tidak jarang perkara yang demikian menjadi kontroversial dimasyarakat karna persepsi dan pemaknaan yang berbeda.

Kemudian bagaimana penerapan terhadap kejahatan Cyberbullying disosial media dalam hukum positif di Indonesia, mengacu pada Undang-undang ITE yaitu pasal 27 sebagaimana telah diuraikan diatas dan bagi mereka yang melakukan pelanggaran yang memenuhi unsur pada pasal 27 ayat (3) tersebut adalah adalah diancam pidana dengan pidana penjara paling lama 6 (enam) tahun dan/atau denda setinggi-tingginya 1.000.000.000, (satu milyar rupiah) (Putra, 2015).

Lebih lanjut relevansi putusan Mahkamah Konstitusi nomor 50/PUUVI/2008 terkait dengan Cyberbullying, "pengaturan kejahatan berdimensi baru yang memilki aspek global ataupun transnasional, jika ditempatkan pada keseluruhan peraturan hukum nasional mencakup peraturan hukum pidana umum dalam KUHP ( Kitab UndangUndang Hukum Pidana ), Dengan perkembangan jaman dalam dimensi yang baru sangat diperlukan pula pengaturan yang sesuai dengan adanya kejahatan cyberbcrime".

Sehingga dalam Undang-undang ITE, cyberbullying dapat dikategorikan dalam kejahatan jenis baru bisa dilihat dari media yang digunakan dalam melakukan kejahatan, yaitu media elektronik dalam bentuk media sosial. (Mulyono, 2017) akibat dan dampak negatif dari cyberbullying adalah dampak negatif bagi para korbannya dimana dampak psikilogis yang dimana membuat para korbannya kehilangan kepercayaan diri lalu dampak psikologis dapat membuat korbannya ingin atau menjadi mengakihiri hidupnya.
Seperti halnya kasus bunuh diri yang dilakukan oleh siswi SMP di SMP Negeri 147, Ciracas, Jakarta Timur. Yang sering dibully oleh teman temannya baik di sekolah atau di media sosial Twitter, sehingga Korban depresi dan mengakhiri hidupnya dengan lomat dari lantai 4 sekolahnya (CNN Indonesia, 2020). Cyberbullying merupakan sebuah fenomena kejahatan baru yang harus mendapatkan perhatian khusus oleh penegak hukum, dikarenakan semakin maraknya kasus yang terjadi baik dalam negeri maupun diluar negeri.

Dalam hukum positif diindonesia memasukkan perbuatan pencemaran nama baik ini dalam hukum pidana dan memiliki hukuman yang cukup berat. Pencemaran nama baik sebagai tindakan bullying yang digunakan melalui media sosial memang regulasinya mengacu pada UU ITE akan tetapi tidak bisa dipungkiri bahwa adanya tindakan bullying ada juga yang dilakukan secara konvensional tanpa menggunakan jaringan internet atau cyberbullying yang berlanjut dengan tindakan bullying secara konvensional. Maka regulasi yang yang tersedia untuk menjerat pelaku bullying konvensional adalah pasal 310 KUHP yang berbunyi: "Barang siapa sengaja menyerang kehormatan atau nama baik seseorang dengan menuduhkan sesuatu hal, yang dimaksudnya terang supaya hal itu dikehatui umum, diancam karena pencemaran dengan pidana penjara paling lama Sembilan bulan atau pidana denda paling banyak empat ribu lima ratus rupiah." dan pasal 310 ayat (2) KUHP yang berbunyi: "Jika hal itu dilakukan dengan tulisan atau gambaran yang disiarkan, dipertunjukkan atau ditempelkan di muka umum, maka diancam karena pencemaran tertulis dengan pidana penjara paling lama satu tahun empat bulan atau pidana denda paling banyak empat ribu lima ratus rupiah".

Tindak pidana yang mempunyai unsur pencemaran nama baik dalam UU ITE maupun dalam KUHP merupakan suatu delik aduan. Terminologi, "mendistribusikan, mentranmisikan, atau dapat membuat dapat diakses nya Informasi Elektronik atau dokumen Elektronik" dalam pasal 27 ayat (3) 
Undang-undang ITE esensinya adalah penghinaan dengan cara baru atau modus operandi baru dengan memanfaatkan media elektronik / media sosial, oleh sebab itu unsur "mendistribusikan, mentransmisikan dan membuat dapat diaksesnya" adalah suatu tindakan-tindakan dalam dunia cyber. Akan tetapi berdasarkan Putusan Mahkamah Konstitusi Nomor 50/PUU-VI/2008 menyebutkan bahwa unsur "dimuka umum" atau "diketahui umum" tidak terpenuhi dalam hal pasal 27 ayat (3) serta 310 KUHP tidak dapat digunakan untuk menjerat cyberbullying.

Sedangkan ketentuan pasal 310 dan pasal 311 adalah ketentuan pidana untuk pencemaran nama baik konvesional. Akan tetapi cyberbullying yang menggunakan jaringan internet terlebih "bully" yang dilakukan melalui sosial media maka aspek yuridis pengaturan terkait adalah mengacu pada pasal 29 UU ITE yaitu: "Setiap orang dengan sengaja dan tanpa hak mengirimkan informasi elektronik dan/ atau dokument yang berisi ancaman kekerasan atau menakut-nakuti yang ditujukan secara pribadi". Informasi elektronik yang dimaksud termasuk dalam ketentuan pasal tersebut termasuk didalammnya "bully" yang dikemukakan dengan jaringan internet melalui berbagai aplikasi sosial media yang tersedia. Sedangkan untuk ketentuan Pidananya jika melanggar ketentuan pasal tersebut diatur dalam pasal 45 B yaitu: "Setiap orang yang dengan sengaja dan tanpa hak mengirimkan informasi elektronik dan/atau dokument elektronik yang berisi ancaman kekerasan atau menakut-nakuti yang ditujukan secara pribadi sebagaimana dimaksud dalam pasal 29 dipidana dengan pidana penjara paling lama 4 (empat) tahun dan/ atau denda paling banyak Rp.750.000.000,-( tujuh ratus lima puluh juta rupiah)".

Dalam penjelasan pasal dalam UU ITE revisi terakhir tepatnya pasal 45 B sudah sudah menambahkan makna dari cyberbullying dengan bunyi kalimat lengkapnya: "Ketentuan dalam pasal ini termasuk juga di dalamnya perundungan di dunia siber (cyber bullying) yang mengandung unsur ancaman kekerasan atau menakut-nakuti dan mengakibatkan kekrasan fisik, psikis, dan/atau kerugian materiil".

Lebih lanjut "Bully" yang dilakukan dalan tindakan konvensional maupun yang dilakukan dalam bentuk Cyberbullying sama-sama merupakan delik aduan. Artinya suatu perbuatan tersebut baru bisa diproses secara hukum untuk proses pidananya bilamana ada pengaduan langsung dari korban perbuatan pidana tersebut.

Ketentuan khusus lainnya juga mengatur perbuatan yang hampir sama diatur juga dalam Undang-Undang Nomor 23 Tahun 2002 tentang Perlindungan Anak sekalipun dengan ancaman pidana pokok yang lebih ringan dibandingkan dengan pasal 29 UU ITE, yaitu pasal 80 yang berbunyi: "setiap orang yang melakukan kekejaman, kekerasan atau ancaman kekerasan, atau penganiayaan anak, dipidana penjara paling lama 3 (tiga) tahun 6 (enam) bulan dan/atau denda paling banyak $R p$. 72.000.000", serta "jika perbuatan tersebut mengakibatkan anak luka berat, pelaku dipidana penjara paling lama 5 (lima) tahun dan/denda paling banyak Rp. 100.000.000."

\section{Simpulan}

Perbuatan "Bully" yang menyebabkan kerugian bagi orang lain merupakan suatu tindak pidana. Jika "Bully" yang dilakukan tersebut secara konvensional dan menyerang kehormatan atau nama baik orang lain termasuk yang dikemukakan dimuka umum maka perbuatan tersebut bisa diancam pidana pasal 310 ayat (1) dan ayat (2) KUHP. Sedangkan jika "Bully" yang dilakukan di dunia maya atau perbuatan "Bully" tersebut dalam bentuk informasi elektronik yang melanggar kesusilaan, penghinaan, pemerasan atau pengancaman maka perbuatan tersebut diancam pidana Pasal 27 ayat (1), (3) dan (4) jo Pasal 45 (1) UU ITE. Sedangkan jika informasi elektronik tersebut berisi ancaman kekerasan atau menakut nakuti secara pribadi diancam pasal 29 jo Pasal 45B UU RI No. 19 Tahun 


\section{Jurnal Cakrawala Hukum, Volume 11 No. 3 Desember 2020}

ISSN PRINT 2356-4962 ISSN ONLINE 2598-6538

2016 perubahan dari UU RI No. 11 Tahun 2008 tentang ITE, sekaligus pasal tersebut adalah pasal yang paling spesifik yang bisa diterapkan pada cyberbullying di media sosial terlebih atas pelengkap yang di muat dalam penjelasan pasal 45B tersebut.

Penyebab timbulnya bullying yang terjadi di sosial media ada beberapa faktor adanya rasa iri terhadap pengguna sosial media yang lain, kemudian rasa balas dendam dikarenakan wujud sebagai tindakan bully yang didapatkan sebelumnya, merasa puas akan tindakannya untuk meluapkan keagresifitasnnya lalu adanya karakteristik dari cyberbullying ialah hal yang disengaja oleh pelaku yang memiliki tujuan tertentu dan telah menetapkan target sebagai korban yang akan di sakiti, tindakan yang membahayakan seperti halnya pengancaman yang dilakukan, hal tersebut akan dilakukan secara berulang-ulang karena memiliki rasa tangguh yang mendominasi sehingga korban merasa tak berdaya dalam membela diri.

\section{Daftar pustaka}

Arif, Barda Nawawi. 2006. Kapita Selekta Hukum Pidana. Cet. III. Citra Aditya Bakti. Bandung.

Budhijanto, Danrinvanto. 2010. Hukum Telekomunikasi, Penyiaran \& Teknologi: Informasi: Regulasi \& Konvergensi. Cetakan I, RAfika Aditama. Bandung.

Cazawi, Adami. 2012. Pelajaran Hukum Pidana Bagian I (Stelsel Pidana, Tindakan Pidana, Teori-teori Pemidanaan, dan Batas Berlakunya Hukum Pidana). Cetakan VII. RajaGrafindo Persada. Jakarta.
Coloroso, Barbara. 2009. Penindas, Tertindas, dan Penonton; Resep Memutus Rantai Kekerasan Anak dari Prasekolah hingga SMU. Serambi Ilmu Pustaka. Jakarta.

Ilyas, Amir. 2012. Asas-Asas Hukum Pidana. Rangkan Education Yogyakarta dan Pukap Indonesia, Yogyakarta.

Makarim, Edom. 2004. Kompilasi Hukum Telematika. RajaGrafindo Persada. Jakarta.

Mansur, Didik Arief. dkk. 2005. Cyber law-Aspek Hukum Teknologi Informasi. Refika Aditama. Jakarta.

Maskun, 2013, Kejahatan Siber, Cybercrime. Kencana Prenada Media Group. Jakarta.

Mulyono, G.P., 2017. Kebijakan formulasi tindak pidana pencemaran nama baik dalam bidang teknologi informasi. Jurnal Cakrawala Hukum, 8(2), pp.160170.

Putra, E. N. (2015). Kejahatan Tanpa Korban Dalam Kejahatan Cyberporn. Jurnal Cakrawala Hukum, 6(1), 1-12.

Priyatna, Andri. 2019. Let's End Bullying: Memahami Mencegah, dan Mengatasi Bullying. Elex Media Komputindo. Jakarta.

Soekanto, Soejono. dkk. 2001. Penelitan Hukum Normatif (satu Tinjauan Singkat). Rajawali Pers. Jakarta.

Suhariyanto, Budi., 2012. Tindak Pidana Teknologi Informasi (CyberCrime) Urgensi Pengaturan dan Celah Hukumnya, Rajawali Pers. Bandung.

Suseno, Sigid. 2012. Yurisdiksi Tindak Pidana Siber. Refika Aditama. Bandung.

Wahid, Abdul. dkk. 2005. Kejahatan Mayantara, Refika Aditama, Bandung. 